Click www.researchjournal.co.in/online/subdetail.html to purchase.

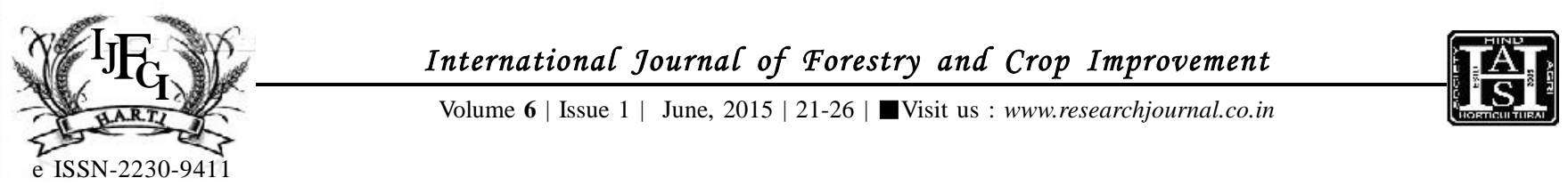

RESEARCH ARTICLE

DOI: $10.15740 / \mathrm{HAS} / \mathrm{IJFCI} / 6.1 / 21-26$

\title{
Summer sesame response to moisture and thermal regimes
}

\author{
K.N. SONDARVA, H.D. RANK AND P.S. JAYSWAL
}

\begin{abstract}
A field experiment was conducted at instructional farm of soil and water engg., CAET, JAU, Junagadh during summer season (Feb.-May), 2012 to study the summer sesame response to moisture and thermal regimes with three Factorial Strip Plot Design. The crop was exposed to different thermal regimes by four dates of sowing i.e., $1^{\text {st }} \mathrm{Feb} ., 14^{\text {th }}$ Feb., $1^{\text {st }}$ March and $14^{\text {th }}$ March with moisture regimes by varying the irrigation interval (3, 4 and 5 days irrigation interval). Results revealed that the seasonal depth of irrigation decreased with delay in sowing from $1^{\text {st }}$ February and the growing days requirement decreased with delaying sowing after $1^{\text {st }}$ February. The more number of growing days were required to mature the crop with less total thermal heat unit. The sesame yield is significantly influenced by the thermal regimes. The highest and lowest sesame grain yield of $1131.59 \mathrm{~kg} /$ ha and $555.20 \mathrm{~kg} / \mathrm{ha}$ was observed for the dates of sowing of $16^{\text {th }}$ February and $1^{\text {st }}$ February, respectively. The grain yield increased rapidly by delaying the sowing from $1^{\text {st }}$ Feb. to $21^{\text {st }} \mathrm{Feb}$., then after it decreased slowly and continously. The vegetative stage was found the most sensitive stage to thermal regimes followed by establishment stage, flowering stage, ripening stage and reproductive stage. The highest grain yield of $991.27 \mathrm{~kg} / \mathrm{ha}$ was found under drip irrigation at 3-days interval which was higher by the tune of 10.33 per cent, 17.32 per cent and 20.86 per cent as compared to that of under 4, 5 days under drip and 7 -days under surface irrigation, respectively.
\end{abstract}

KEY WORDS : Summer, Sesame, Moisture, Thermal regimes

How TO CITE THIS ARTICLE : Sondarva, K.N., Rank, H.D. and Jayswal, P.S. (2015). Summer sesame response to moisture and thermal regimes. Internat. J. Forestry \& Crop Improv, 6 (1) : 21-26.

ARTICLE ChroniCAL : Received : 12.11.2014; Revised : 08.04.2015; Accepted : 11.05.2015 